\title{
Geotourist potential of the Padis Karst Region (Apuseni Mountains, Romania)
}

\author{
Potencjał geoturystyczny krasowego regionu Padis \\ (Góry Apuseni, Rumunia)
}

\author{
Magdalena Górna \\ Wydziat Geologii, Geofizyki i Ochrony Środowiska, \\ Akademia Górniczo-Hutnicza, Al. Mickiewicza 30, 30-059 Kraków, \\ e-mail:mgorna@geol.agh.edu.pl
}

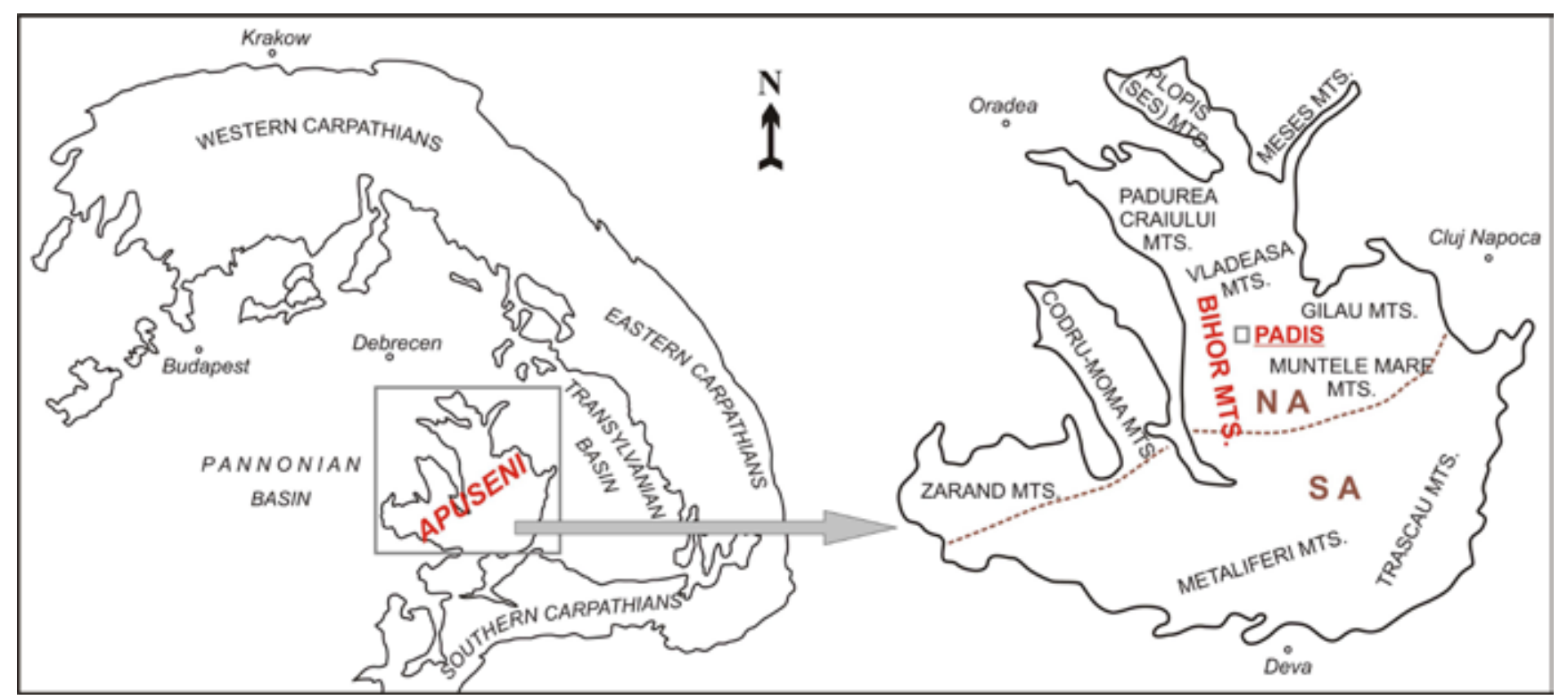

Fig. 1. Sketch map of the Carpathians with geographical sub-division of the Apuseni, boundary between structural units: The North Apuseni (NA) and The South Apuseni (SA) and location of the Padis region (after Seghedi, 2004; modified). Schematyczna mapa Karpat wraz z podziałem geograficznym Apuseni, granicą pomiędzy jednostkami strukturalnymi: Północnymi Apuseni (NA) i Południowymi Apuseni (SA) oraz lokalizacją regionu Padis (wg Seghedi, 2004; zmodyfikowano).

\begin{abstract}
The paper presents the remarkable Padis region, which is one of the most attractive and the best developed karst areas in the Carpathian Mountains. The karst forms, which should be promoted as geotourist sites, were selected on the basis of established criteria, and described. Moreover, the forms of nature conservation are emphasized, as well as strong and week points of tourist infrastructure. Actions leading to adapt this region for geotourism were suggested.
\end{abstract}

Key words: Padis plateau, karst forms, geotourism development.

Treść: Artykut przedstawia unikatowy region Padis, który należy do najatrakcyjniejszych i najlepiej wykształconych krasowych obszarów w Karpatach. Na podstawie przyjętych kryteriów wytypowano, a nastęnie scharakteryzowano formy krasowe, które powinny być promowane jako obiekty geoturystyczne. Ponadto zwrócono uwage na formy ochrony przyrody, mocne $i$ stabe strony infrastruktury turystycznej oraz zaproponowano działania majace na celu zaadaptowanie regionu dla potrzeb geoturystyki.

Slowa kluczowe: płaskowyz Padis, formy krasowe, zagospodarowanie geoturystyczne.

\section{Introduction}

The Padis region is located in north-west Romania, in northern part of Bihor Mountains, which are the middle and the highest part of the Apuseni Mountains (Fig. 1). Traditionally, the name "Padis region" is related to the area between upper course of the rivers: Somesul Cald, Aries and Crisul Negru. The Padis plateau is the main part of this area. This 1200-1400 m high plateau is enclosed by mountain peaks (Fig. 2) and occupies the area of $37 \mathrm{~km}^{2}$ (Móga, 2002). This paper concerns the geotourist potential of the Padis plateau and the nearest surroundings.

\section{Geology \& relief}

The Apuseni Mountains consist of two different structural units: The North Apuseni, which includes Bihor Mountains and The South Apuseni (Fig. 1). The North Apuseni are composed of Permo-Mesozoic shallow marine and nonmarine sedimentary cover and volcanic rocks that overlie Proterozoic metamorphic rocks and Paleozoic granites (Burchfiel et al., 


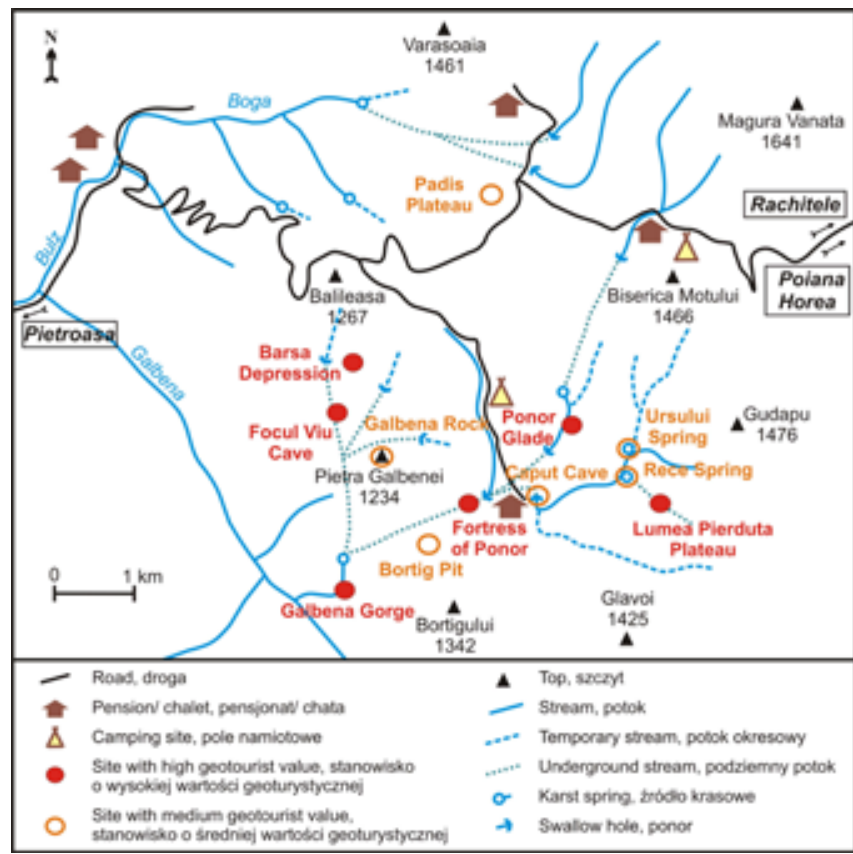

Fig. 2. Sketch map of the Padis plateau with location of the selected sites • Poglądowa mapa płaskowyżu Padis wraz z lokalizacją wybranych stanowisk

1974; Seghedi, 2004). The sedimentary cover starts with Permian and Lower Triassic conglomerates, quartzite sandstones and red shales. The thick series of Triassic carbonate deposits includes gray dolomites (Campilian-Anisian), followed by white reef limestones (Ladinian). This carbonate formation is transgressively overlaid by the Lower Jurassic deposits: quartzite sandstones and conglomerates, shales and black limestones (Hettangian-Lower Sinemurian), reddish and gray limestones, marls and marly limestones (Upper Sinemurian-Toarcian). The Jurassic series end with carbonatic platform deposits, mostly reef limestones (Oxfordian- Lower Tithonic). The Lower Cretaceous series are developed as limestones, marls and turbidites (Bleahu et al., 1968; Orăşeanu et al., 2007). The North Apuseni are composed of the following tectonic elements: the Codru Nappe Complex, the Biharia Nappe Complex and the Bihor autochthon (Bleahu et al., 1968).

The entire area of Padis region belongs to the Bihor autochthon. From among karstified rocks mostly Jurassic limestones dominate in the southern part of described plateau. The northern part is build of Triassic limestones and dolomites. This carbonated rocks rest on crystalline slates and on Permian, Lower Triassic and Lower Jurassic detritic deposits (Fig. 3). The sedimentary cover of the Bihor autochton forms a monoclinal structure slanting towards SW (Bleahu et al., 1968; Móga, 2002).

The occurrence of sequence of karstified and non-karstified rocks provided a favourable conditions for development of diversified relief. In a relatively small area visitor can encounter magnificent surface and subsurface karst forms like caves, karst pits (avens), swallow holes (ponors), karst springs, gorges and dolines. This region is characterized by the great geotourist potential and with good reason is called the kingdom of the Carpathians karst.

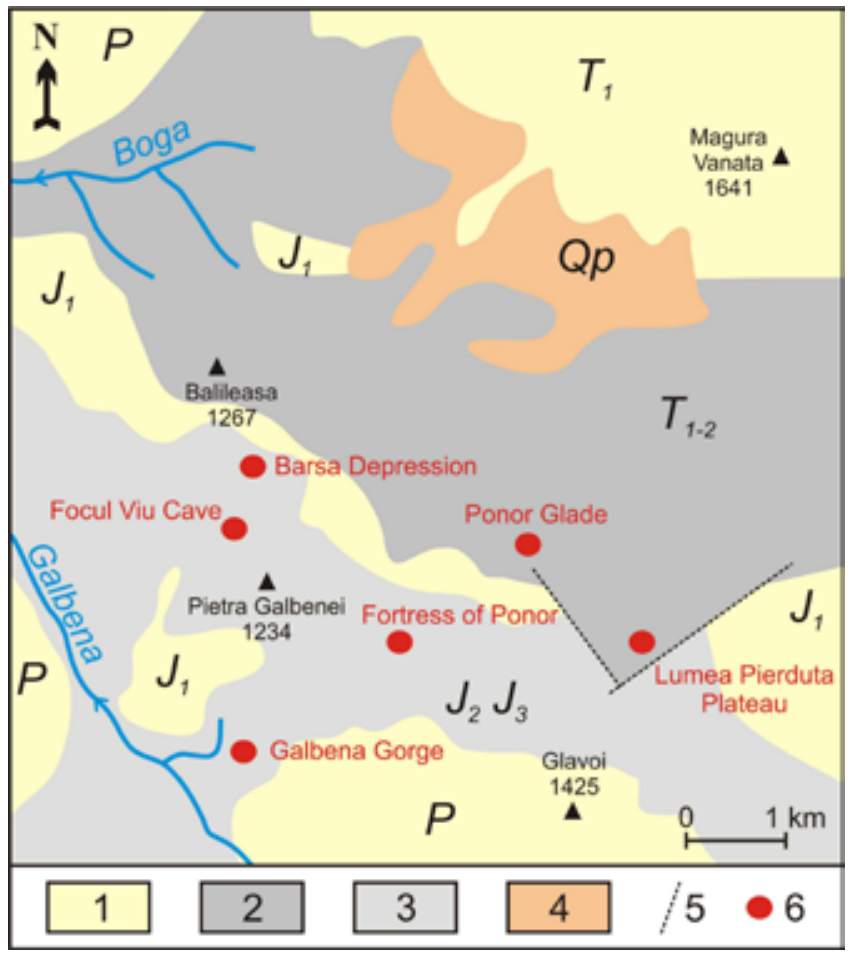

Fig. 3. Geological sketch map of the Padis plateau (after Bleahu et al., 1968; Móga, 2002; modified); 1 - non-karstified rocks: sandstones, conglomerates, shales $\left(P, T_{1}, J_{1}\right), 2$ - limestones and dolomites $\left(T_{1-2}\right)$, 3 - limestones $\left(\mathrm{J}_{2,3}\right), 4$ - gravels, clays, sands $(\mathrm{Qp}), 5$ - fault, 6 - sites described in text. - Schematyczna mapa geologiczna płaskowyżu Padis (wg Bleahu i in., 1968; Móga, 2002; zmodyfikowano); 1 - skały niekrasowiejące: piaskowce, zlepieńce, łupki $\left(\mathrm{P}, \mathrm{T}_{1}, \mathrm{~J}_{1}\right), 2$ - wapienie i dolomity $\left(\mathrm{T}_{1-2}\right), 3$ - wapienie $\left(\mathrm{J}_{2,3}\right), 4$ - żwiry, gliny, piaski (Qp), 5 - uskok, 6 - stanowiska opisane $\mathrm{w}$ tekście.

\section{Geotourist assessment}

The valuation of geological environment is a key element of estimation of geotourist potential, furthermore, it is particularly important for the future geotourism management. The results of the assessment enable to compare and classify the sites and offer suggestions for their promotion, protection and development.

There are plenty of karst forms in the Padis region, but not all should be promoted as geotourist sites. In order to identify the most valuable sites, the assessment process is essential. The following criteria were taken into account during valuation: scientific value (rareness in relation to described area, condition of outcrop and ilustrativeness- opportunity to observe karst phenomena and their connection with geological structure), location (accessibility- difficulty of exploring; only freely available sites were considered, unnecessary speleological equipment) and additional values (aesthetic value, development and legal protection) (tab. 1). The assessment of sites is carried out with using the point bonitation method, which assumes the assignment of the numerical values (points) to individual features of the site, according to the established criteria and scale (Sołowiej, 1992). The scale value is from 1 to 2 (for 6 indicators) or equals 1 (for 1 indicators). The value of feature may equals 0 when it is below the proposed criteria. It should be noted that the criteria like size 


\begin{tabular}{|c|c|c|}
\hline \multicolumn{3}{|r|}{ Scientific value Sc } \\
\hline \multirow{3}{*}{$\begin{array}{l}\text { Rareness in relation to described area } \\
\text { Rar }\end{array}$} & 1 & Site one from several similar \\
\hline & 1,5 & One of the most important \\
\hline & 2 & The only occurrence \\
\hline \multirow{2}{*}{$\begin{array}{l}\text { Condition of outcrop (visibility) } \\
\text { Con }\end{array}$} & 1 & Partly covered with vegetation \\
\hline & 2 & Well exposed \\
\hline \multirow{2}{*}{$\begin{array}{l}\text { Ilustrativeness } \\
\text { Ilu }\end{array}$} & 1 & Low illustrativeness \\
\hline & 2 & Good example of geo(morfo)logical feature or processes \\
\hline \multicolumn{3}{|r|}{ Location Lo } \\
\hline \multirow{2}{*}{$\begin{array}{l}\text { Accessibility } \\
\text { Acc }\end{array}$} & 1 & Access difficult for some tourists \\
\hline & 2 & Available for all tourist \\
\hline \multicolumn{3}{|r|}{ Additional values Add } \\
\hline $\begin{array}{l}\text { Aesthetic value } \\
\text { Aes }\end{array}$ & To 2 & $\begin{array}{l}\text { Subjective value, based on visual singularity of sites, quality of panorama, } \\
\text { attractiveness forms }\end{array}$ \\
\hline $\begin{array}{l}\text { Development } \\
\text { Dev }\end{array}$ & To 2 & $\begin{array}{l}\text { Tourist development for example artificial aids, benches, shelters (1) and information } \\
\text { panel (1) }\end{array}$ \\
\hline $\begin{array}{l}\text { Legal protection } \\
\text { LP }\end{array}$ & 1 & Individual protection as geo(morfo)logical site \\
\hline
\end{tabular}

Tab. 1. Criteria of assessment and their numerical value (own study, based on e.g. Otęska-Budzyn, 1992; Pralong, 2005) • Kryteria waloryzacji i ich wartość liczbowa (opracowanie własne, na podstawie min. Otęska-Budzyn, 1992; Pralong, 2005).

of site and location in relation to tourist trails were not considered. In the case of Padis only sites with the size distinguishing them from the surroundings and located directly by the trails were taken into account. The sum of all indicators determines the total value of sites (maximum 13). Consequently, the sites with scores over $70 \%$ of maximum total value can be considered as sites with high geotourist value, the sites with scores between 69 and $40 \%$ - as sites with

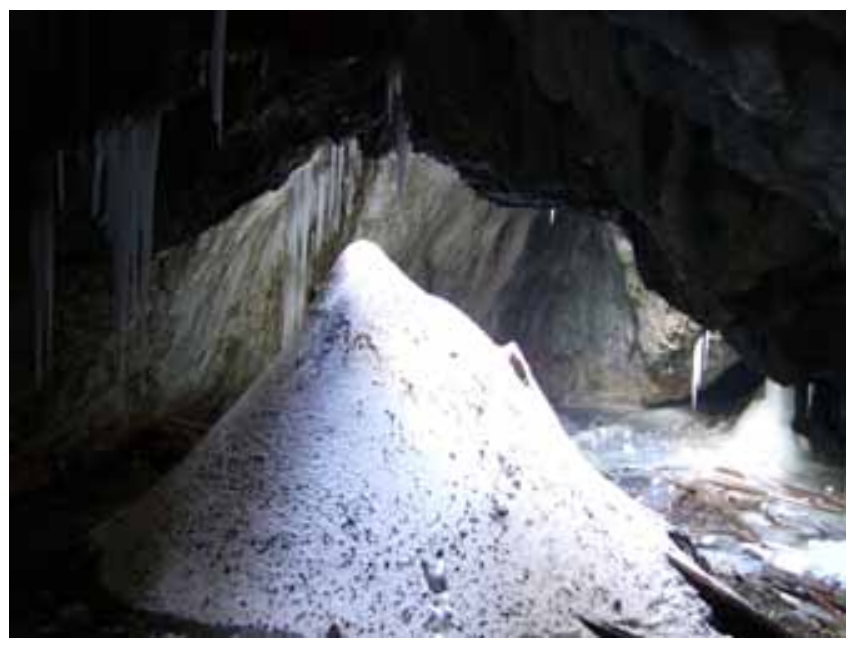

Fig. 4. Ice column in the Focul Viu Ice Cave, phot. M. Górna • Kolumna lodowa w jaskini lodowej Focul Viu, fot. M. Górna

medium geotourist value and the sites with scores under 39\% - as sites with low geotourist value.

Results of the geotourist assessment are summarized in table 2. Six sites, presented below, obtained the score over $70 \%$ of maximum total value and they were recognized as the most valuable for geotourism. All of them are located generally in southern part of the Padis region (Fig. 2).
The Focul Viu Ice Cave is one of the most famous caves of the Padis plateau. This small cave consists of two chambers: the Big Hall $(68 \times 46 \mathrm{~m})$, with the 4-5 m high ice column and ice stalagmites (Fig. 4) and the Small Hall (20x5m). Moreover, the bottom of the Big Hall is occupied by a huge ice block (20 $\mathrm{m}$ thick, $25000 \mathrm{~m}^{3}$ volume) - is the third largest underground mass of permanent ice in Romania (Perşoiu et al., 2007). During the summer time, sunlight falls on ice through a hole in cave's ceiling, giving illusion of flames. This amazing optical phenomenon inspired the name of the cave - Focul Viu means Living Fire. There are two reasons which allow the ice to stay in the cave: the hole in the ceiling which lets cold air inside and the lack of ventilation which traps it and keeps it cold enough all year (Pop, 1998; Galusek, 2004). Visiting the chambers is forbidden for the sake of legal protection, but tourists have the opportunity to observe the interior of the cave from the wooden gallery at the entrance.

The Fortress of Ponor Karst Comlex is without doubt the most amazing and the most famous karst phenomenon in Romania as well as in the all Carpathian Mountains. This complex includes (Fig. 5): a valley called Doline 1, where water cascades over the rocks (Fig. 6), two collapsed dolines: Doline 2 (Fig. 7) and Doline 3, a cave with an underground stream and a famous cave portal, which is $70 \mathrm{~m}$ high (Fig. 8). Doline 2 is a $200 \mathrm{~m}$ deep circular "hole", which is available through the portal and the short and high cave tunnel from Doline 1. Doline 3 has a triangle shape with a $300 \mathrm{~m}$ long margin (Pop, 1998). Access there is possible through Doline 1 after a short climb or through a cave tunnel, but in the latter the speleological equipment could be helpful. There are 4 wooden balconies above Dolines 2 and 3 so there is an opportunity to admire the size and the beauty of the Fortress of Ponor.

The Galbena Gorge is located outside of the Padis plateau. In the Galbena karst spring, which looks like a small lake 
Geotourist potential of the Padis Karst Region (Apuseni Mountains, Romania)

\begin{tabular}{|c|c|c|c|c|c|c|c|c|c|}
\hline \multirow{2}{*}{ Sites Criteria } & \multicolumn{3}{|c|}{ Sc } & \multirow{2}{*}{$\begin{array}{c}\text { Lo } \\
\text { Acc } \\
\end{array}$} & \multicolumn{3}{|c|}{ Add } & \multirow{2}{*}{ Total value } & \\
\hline & Rar & Con & Ilu & & Aes & Dev & $\mathbf{L P}$ & & \multirow{7}{*}{ 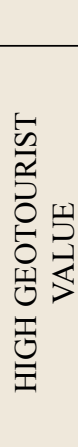 } \\
\hline Focul Viu Ice Cave & 1,5 & 2 & 2 & 2 & 2 & 2 & 1 & 12,5 & \\
\hline Fortress of Ponor Karst Complex & 2 & 2 & 2 & 1 & 2 & 2 & 1 & 12 & \\
\hline Galbena Gorge & 1,5 & 2 & 2 & 1 & 2 & 2 & 1 & 11,5 & \\
\hline Ponor Glade & 2 & 2 & 2 & 2 & 2 & 0 & 0 & 10 & \\
\hline Lumea Pierduta Plateau & 1,5 & 1 & 2 & 2 & 2 & 0 & 1 & 9,5 & \\
\hline Barsa Karst Depression & 1,5 & 1 & 2 & 2 & 2 & 0 & 1 & 9,5 & \\
\hline Padis Plateau & 1,5 & 1 & 1 & 2 & 1 & 1 & 1 & 8,5 & 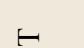 \\
\hline Galbena Rock & 1 & 1 & 1 & 2 & 2 & 0 & 1 & 8 & $\vec{v}$ \\
\hline Caput Cave & 1 & 2 & 1 & 2 & 1 & 0 & 0 & 7 & 통 \\
\hline Bortig Pit Hole & 1 & 1 & 1 & 2 & 1 & 0 & 1 & 7 & $\sum_{i}^{0} \leqslant$ \\
\hline Ursului Karst Spring & 1 & 1 & 1 & 2 & 1 & 0 & 0 & 6 & $\overline{\bar{\imath}}$ \\
\hline Rece Karst Spring & 1 & 1 & 1 & 2 & 1 & 0 & 0 & 6 & \\
\hline
\end{tabular}

Tab. 2. Result of geotourist assessment of karst sites in the limit of the Padis plateau (for explanation of abbreviations - see tab. 1). Wynik waloryzacji geoturystycznej krasowych obiektów płaskowyżu Padis (rozwinięcie skrótów - patrz tab. 1).

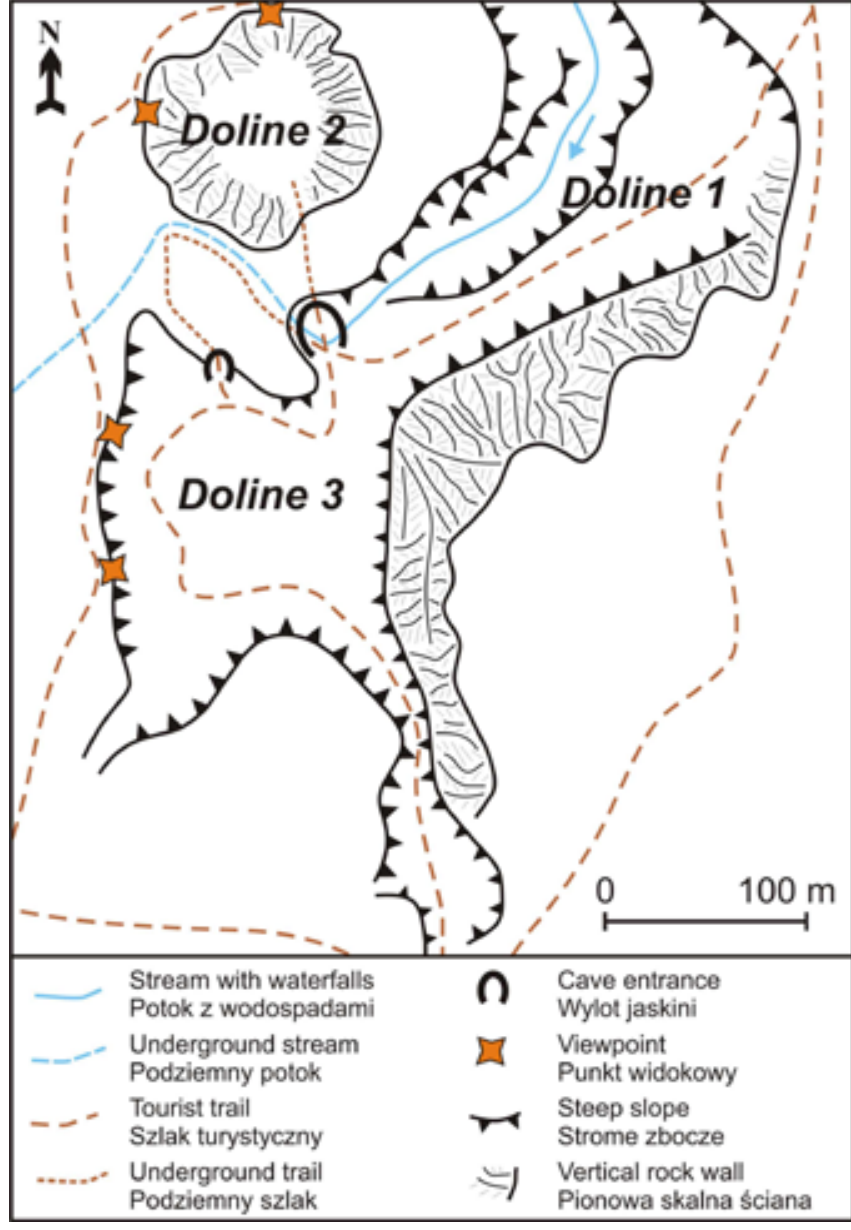

Fig. 5. Sketch map of the Fortress of Ponor Karst Complex (after Vagra, 2005; modified). • Plan kompleksu krasowego Twierdza Ponoru (wg Vagra, 2005; zmodyfikowano).

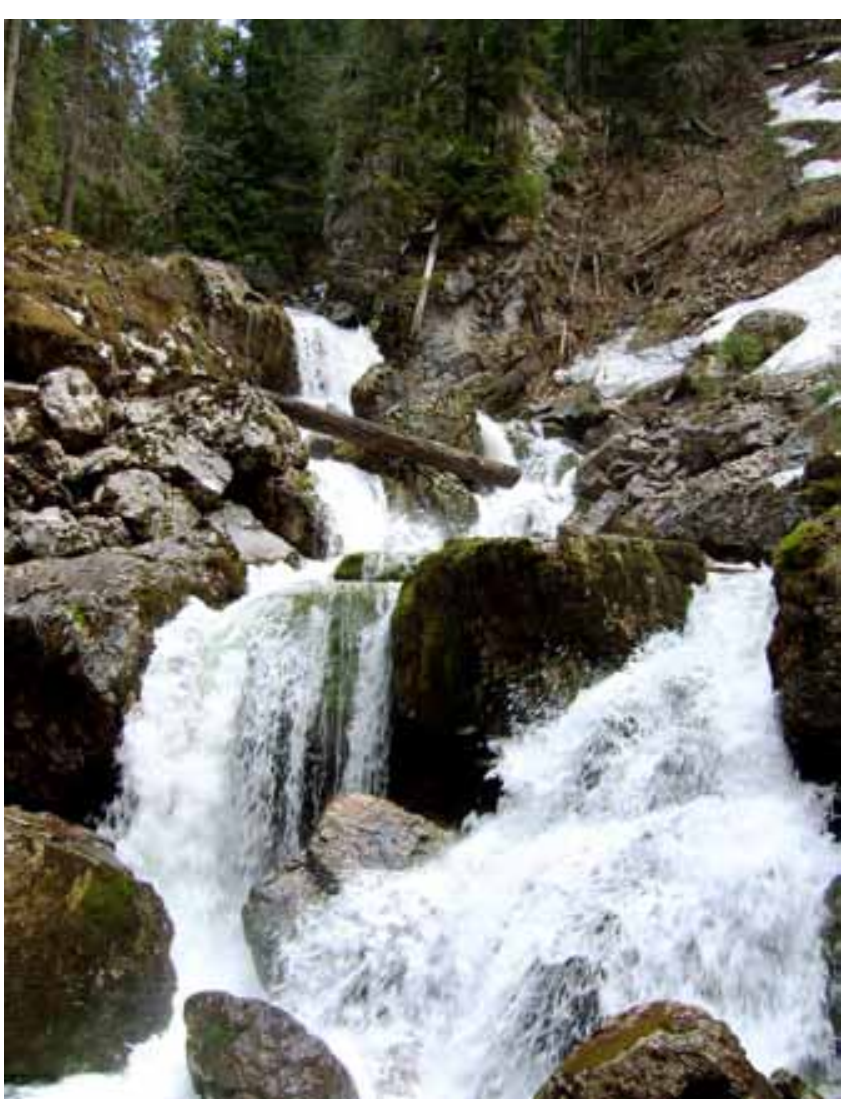

Fig. 6. The Fortress of Ponor- water cascades towards the cave, phot. M. Górna. - Twierdza Ponoru- woda spływająca kaskadami w stronę jaskini, fot. M. Górna.

(Fig. 9), water from the largest part of plateau appears (Fig. 2) (Móga, 2002). The Galbena Valley has formed narrow gorge with vertical walls and several beautiful waterfalls (Fig. 10). The first tourist trail leads through the gorge, but it could be difficult to explore, because of dangerous sections or poor 


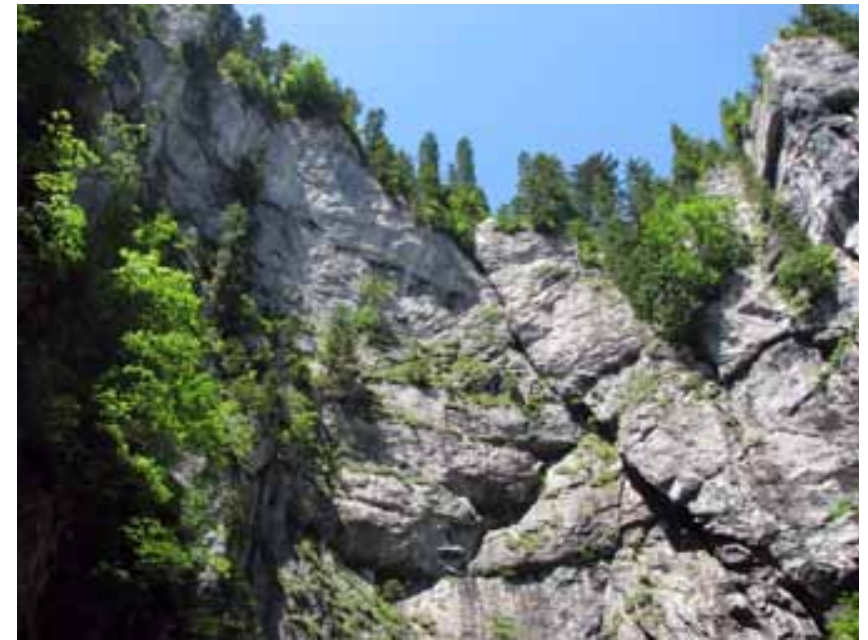

Fig. 7. The Fortress of Ponor - circular doline with a $200 \mathrm{~m}$ high walls, phot. P. Tyrała. - Twierdza Ponoru - owalny lej zapadliskowy o ścianach osiągających $200 \mathrm{~m}$ wysokości, fot. P. Tyrała.

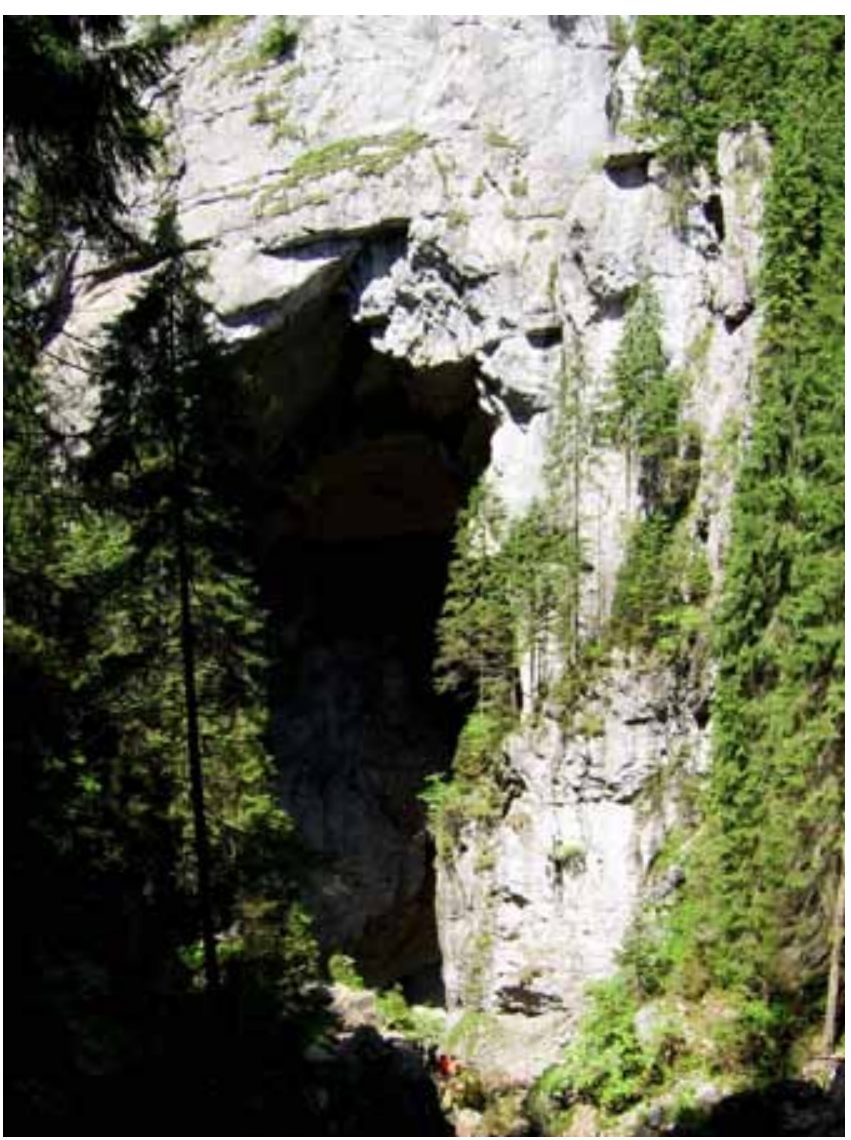

Fig. 8. The Fortress of Ponor - famous cave portal, phot. M. Górna. - Twierdza Ponoru- słynny portal stanowiący wejście do jaskini, fot. M. Górna.

condition of support chains and steel ropes. It is recommended rather to experienced tourists (especially the most spectacular upper part of the gorge), moreover it is forbidden on bad weather or during floods. The second trail climbs above the gorge and leads to a viewpoint suspended $200 \mathrm{~m}$ above the stream (Fig. 11). This viewpoint offers one of the most remarkable panoramas in Bihor Mountains.

The Ponor Glade is the only example of polje in the Padis region (Fig. 12). The most interesting fact here is the water

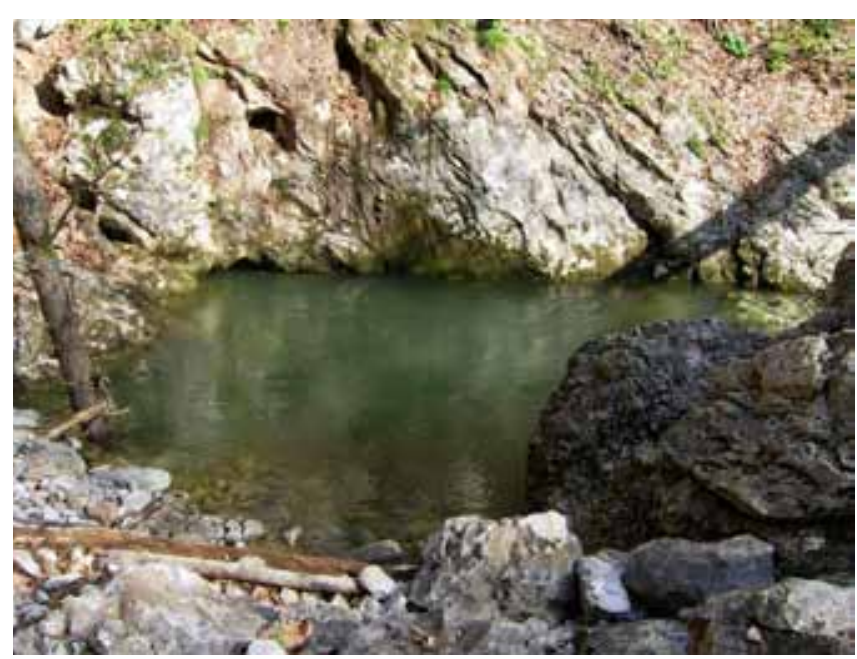

Fig. 9. The Galbena Karst Spring, phot. M. Górna. • Wywierzysko Galbena, fot. M. Górna.

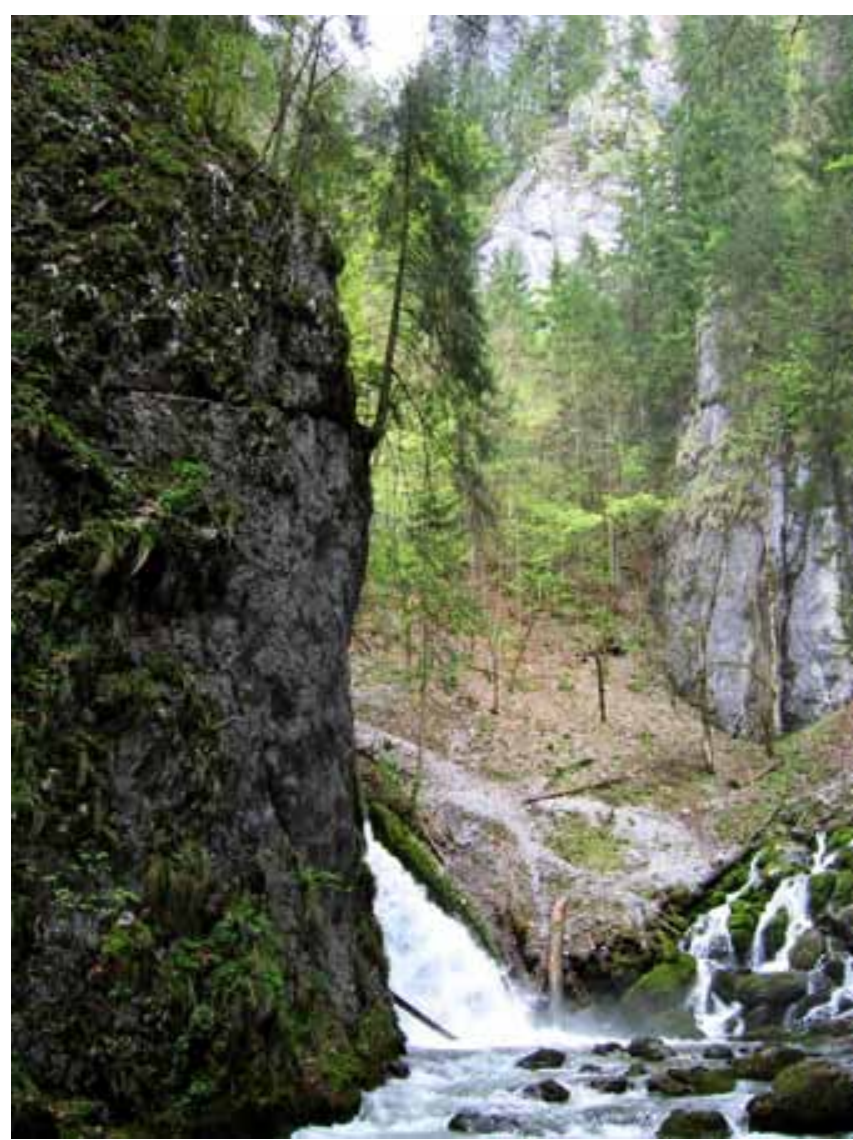

Fig. 10. Vertical walls and waterfalls in the Galbena Gorge, phot. M. Górna. P Pionowe ściany i wodospady w wąwozie Galbena, fot. M. Górna.

draining system. The waters of a part of Magura Vanata Hill appear in karst spring, paradoxically called the Ponor Spring. Then the stream flows through the bottom of the glade and after about $1 \mathrm{~km}$ disappears underground in swallow holes. Usually two swallow holes are active. At high flows, after rain for example, more swallow holes function. But sometimes even these swallow holes are unable to absorb all the water and a part of the glade becomes a temporary lake (Pop, 1998). 


\begin{tabular}{|l|c|c|}
\multicolumn{1}{|c|}{ Name } & Form of protection & Area (ha) \\
\hline Galbena Valley & nature reserve & 30,5 \\
\hline Padis Plateau and Varasoaia Depression & nature reserve & 39 \\
\hline Lumea Pierduta Plateau & nature reserve & 30 \\
\hline Barsa Depression & nature reserve & 14,9 \\
\hline Fortress of Ponor & nature reserve & 6,3 \\
\hline Galbena Rock & nature reserve & 3 \\
\hline Balileasa Depression & nature reserve & 1 \\
\hline Biserica Motului Summit & nature reserve & 0,1 \\
\hline Florilor Glade & nature reserve & 0,1 \\
\hline Bortig Pit & nature monument & nature monument \\
\hline Focul Viu Ice Cave & pat & \\
\hline
\end{tabular}

Tab. 3. Protected sites and areas in the limit of the Padis plateau (after Hansen et al., 2002). • Obiekty i obszary podlegające ochronie w obrębie płaskowyżu Padis (wg Hansen i in., 2002).

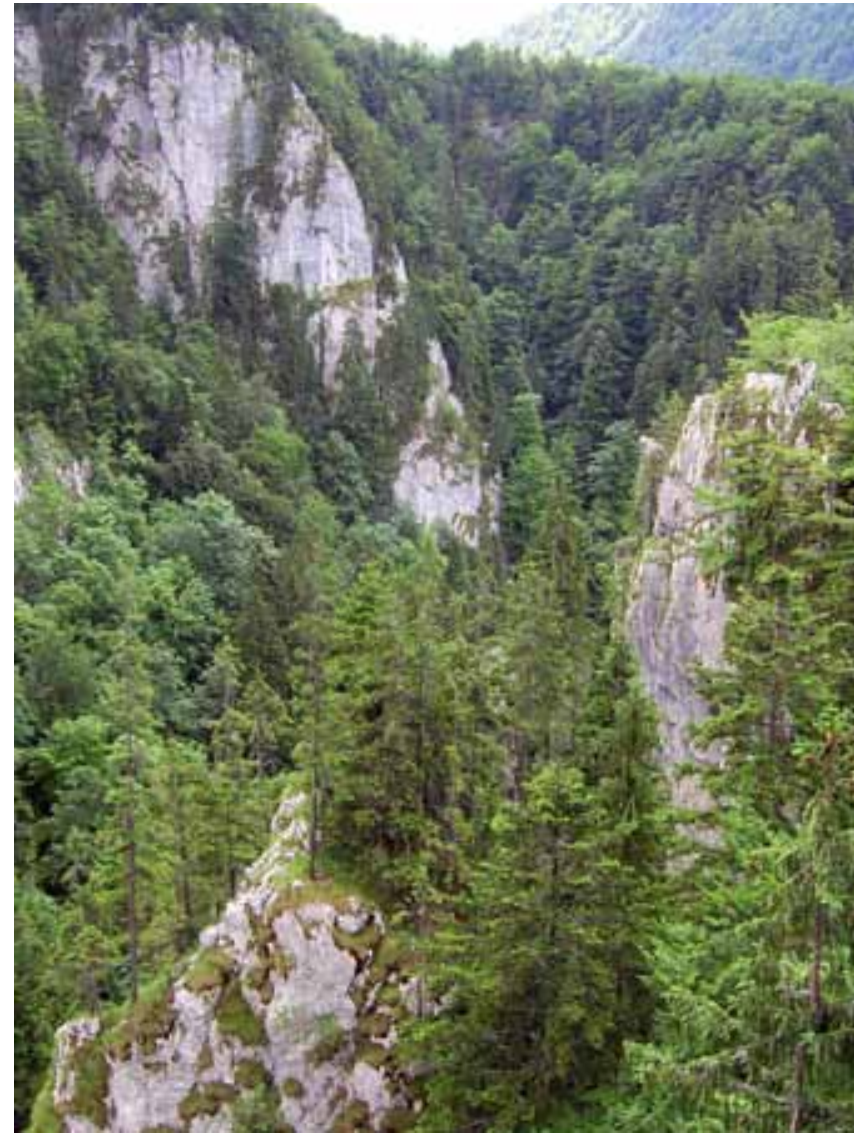

Fig. 11. The view of the Galbena Gorge, phot. M. Górna • Widok na wąwóz Galbena, fot. M. Górna.

The name of the Lumea Pierduta Plateau (Lost World) comes from the past wilderness. Today, this area draws attention with big and deep karst pit holes (avens). The deepest one is the Negru Pit (the Black Pit), it has $50 \mathrm{~m}$ in diameter, and $108 \mathrm{~m}$ vertical deep. The smaller forms are the Gemanata Pit (the Twin Pit, 94 m vertical deep) and the Acoperit Pit (The Covered Pit, $35 \mathrm{~m}$ vertical deep). The Gemanata Pit is the most spectacular because it is cut above the entrance by a natural stone bridge, which divides it into two parts - hence its name (Fig. 13). The Negru and Gemanata Pits are connected through underground cave system. This network

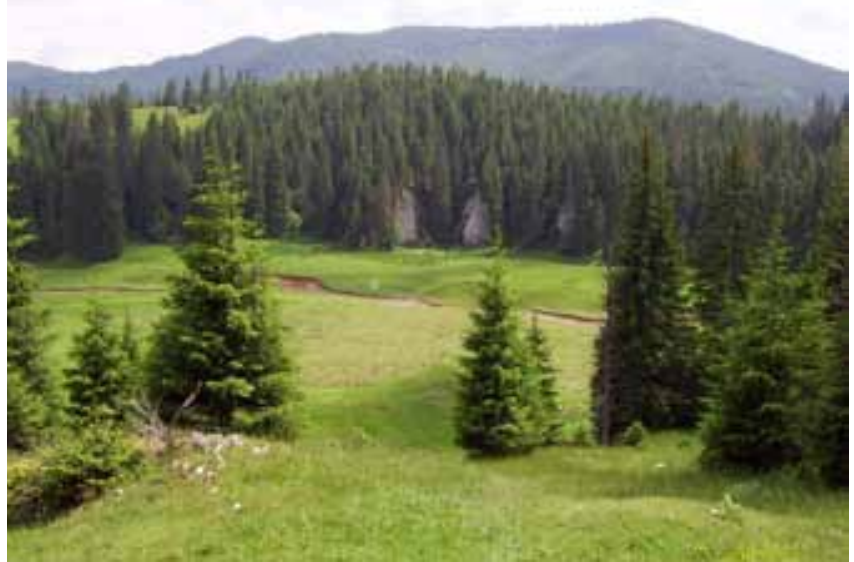

Fig. 12. The view on the Ponor Glade, the only example of polje, phot. M. Górna. - Widok na polanę Ponor, jedyny przykład polia, fot. M. Górna.

is used by underground waters. Part of this network is available for speleologists through the Gemanata Pit (Pop, 1998; Galusek, 2004).

Tourists can find wilderness, thick forest, often blind and dry valleys, karst lake, lots of sink holes and several caves within the Barsa Karst Depression. The longest cave is Zapodie Cave System, which is $11 \mathrm{~km}$ length. It consists of the Zapodie Cave and the Neagre Cave (Fig. 14). The exploration of both caves is recommended only for experienced speleologists. A part of the Barsa Ice Cave is possible to visit for all tourists, but only during favourable conditions, without mud and snow cover at the entrance. Pop (1998) supposes that this cave is connected with Zapodie Cave System.

\section{Nature conservation}

The entire area of the Padis plateau is protected as a part of the Apuseni National Park. The first official act concerning this park was declared in 1990. The limits of the park were established only in 2003, and one year later the administration of the park was formed (www). Moreover, several sites within the limits of the Padis plateau are protected as nature reserves 


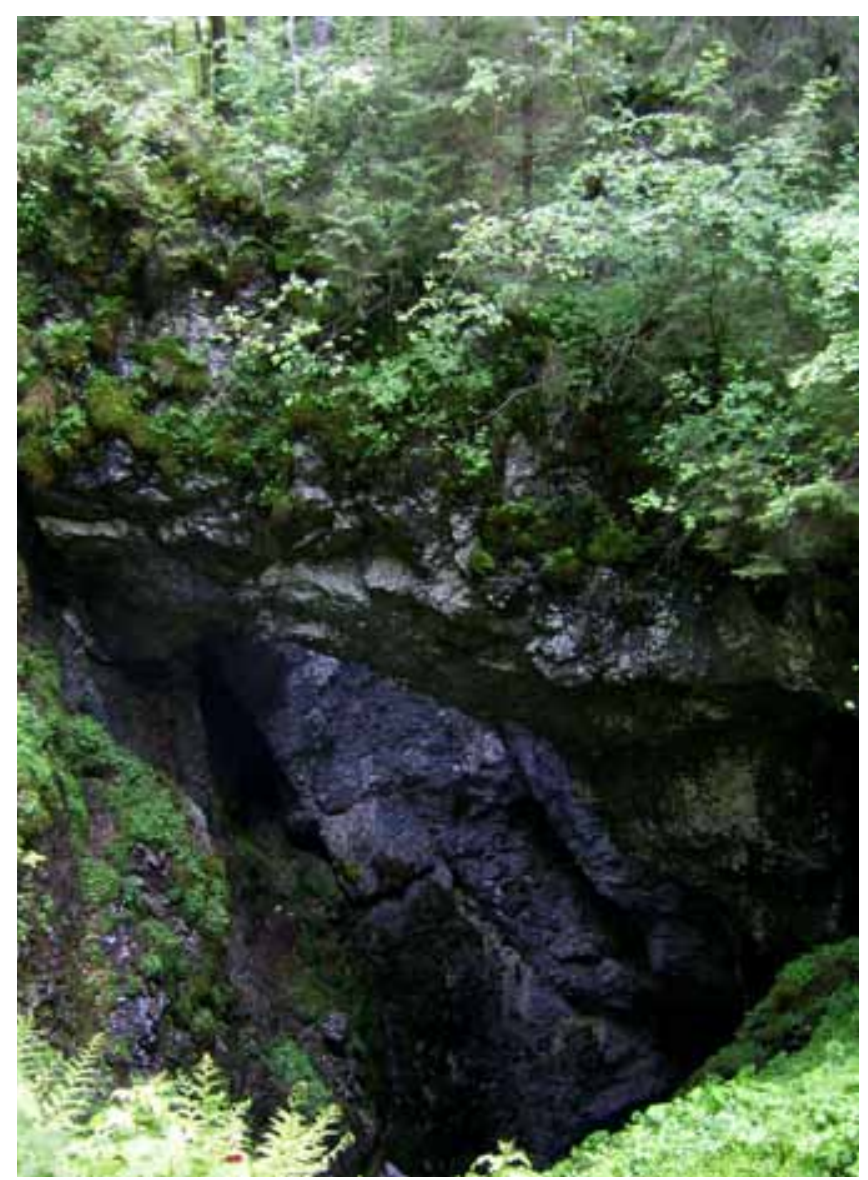

Fig. 13. Stone bridge over the Gemanata Pit, phot. M. Górna. • Kamienny most nad awenem Gemanata, fot. M. Górna. or nature monuments (tab. 3). Although the considered region is under legal protection, this information is not public knowledge. The panels, which should inform visitors of protection, may be found only at three of eleven reserves or monuments. Also noteworthy is the fact that the uncontrolled tourism has negative impact on the nature. The development of geotourism is a chance for the effective conservation of inanimate nature through making local community as well as tourists aware of the value of geological heritage.

\section{Tourism development}

The presented area attracts attention of tourists from Romania and also from abroad. Accessibility as well as accommodation have improved in the last few years. The region is crossed from east to west by a $50 \mathrm{~km}$ long forest road. The shortest $20 \mathrm{~km}$ access to the heart of the Padis leads from the Pietroasa village, another $30 \mathrm{~km}$ road leads from the Rachitele village. The Padis region offers accommodation in private pensions and in chalets called "cabana". In summer time tourists can use two "traditional" camping sites: at the Padis Pension and on the La Grajduri Glade (Fig. 2). Unfortunately these places have no camping facilities like toilets, showers, parking or places for garbage so they need investments to be able to function as "real" camping sites.

In the context of the Apuseni National Park, Padis might become its core with the existing accommodation enlarged by tourist information points. Camping should be strictly regulated with no camping allowed beyond the limits of camping sites. Limited development in this area could then be

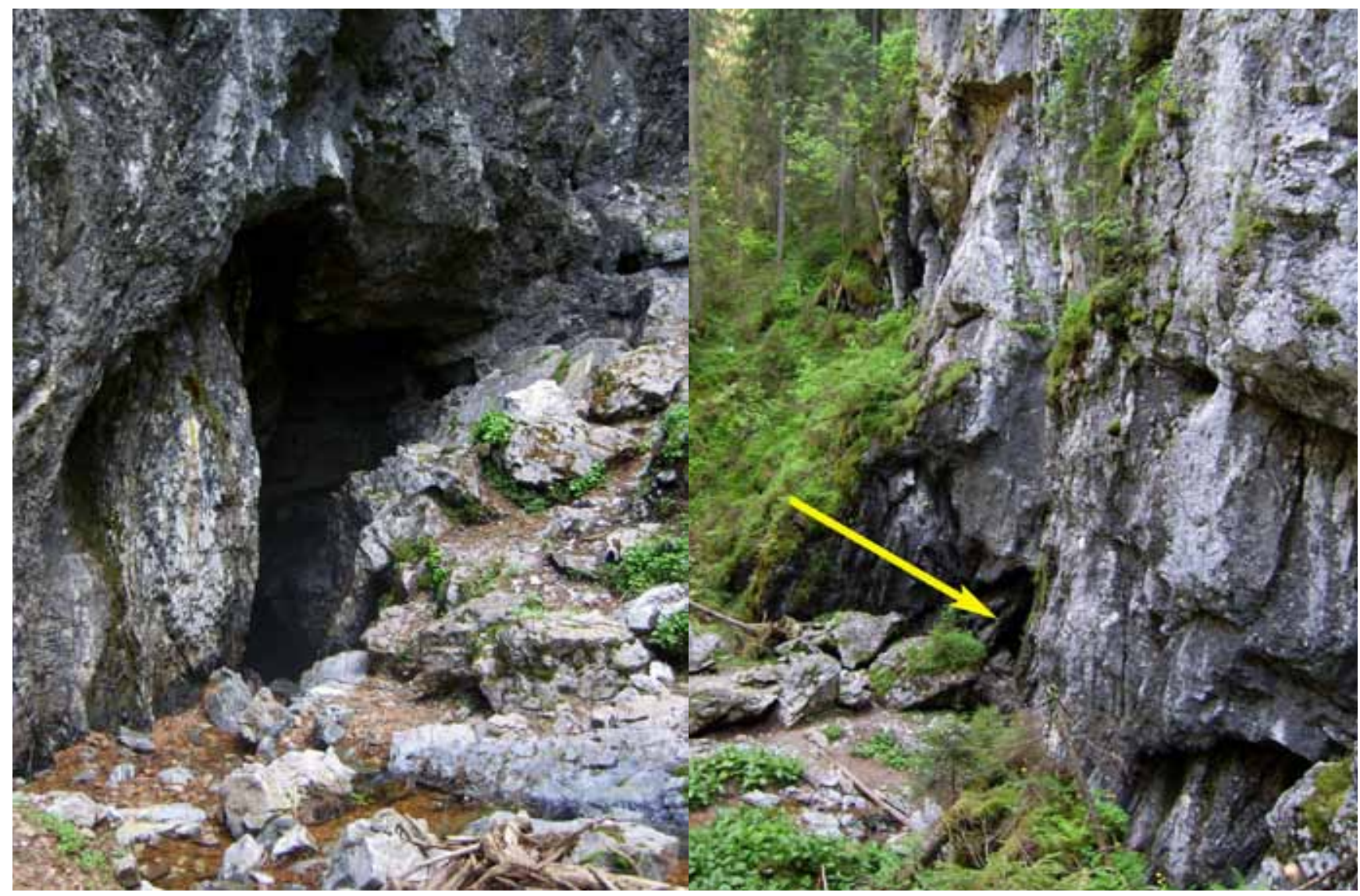

Fig. 14. The entrance to the Neagre Cave, phot. M. Górna. - Wejście do jaskini Neagre, fot. M. Górna. 


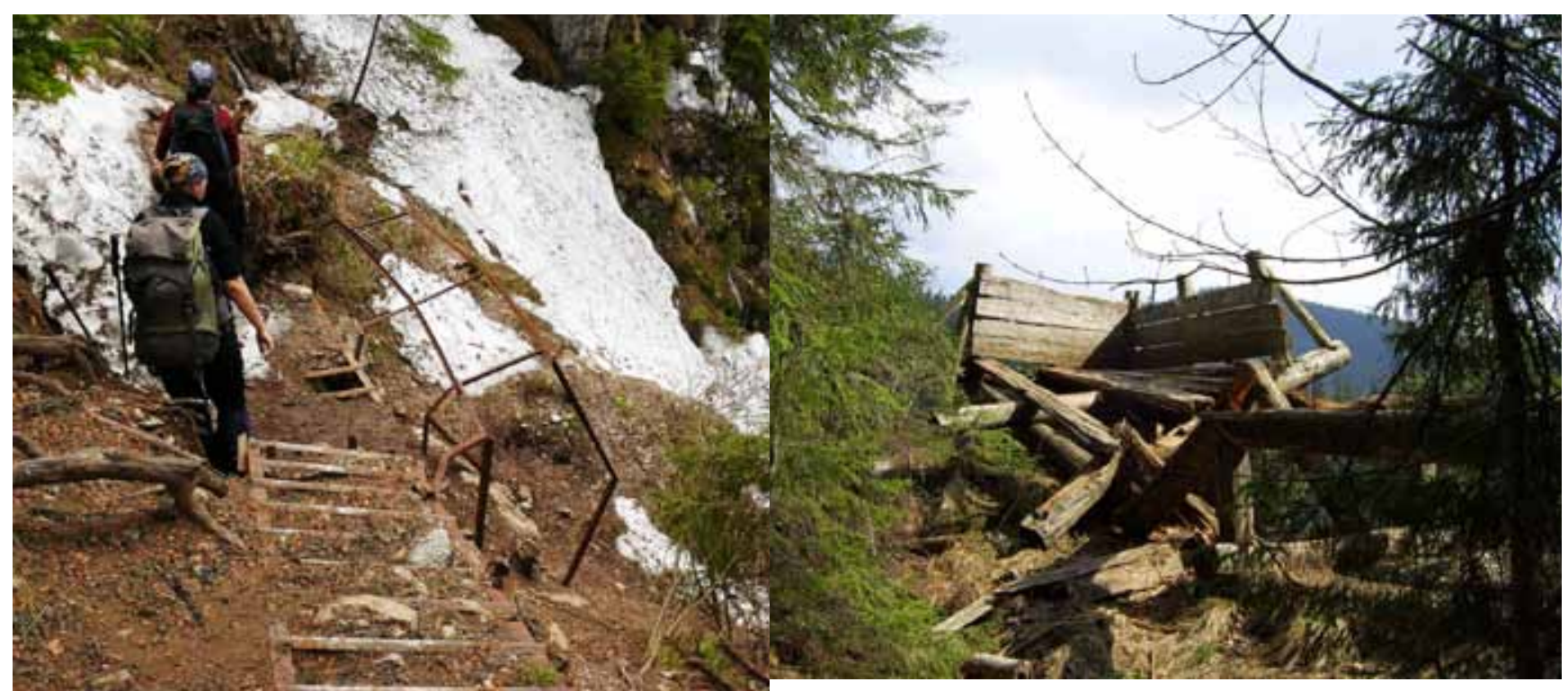

Fig. 15. Examples of poor conditions of technical facilities: stairs and wooden balcony within the Fortress of Ponor, phot. M. Górna. - Przykłady złego stanu udogodnień na szlakach: schody i balkon widokowy w obrębie Twierdzy Ponoru, fot. M. Górna.

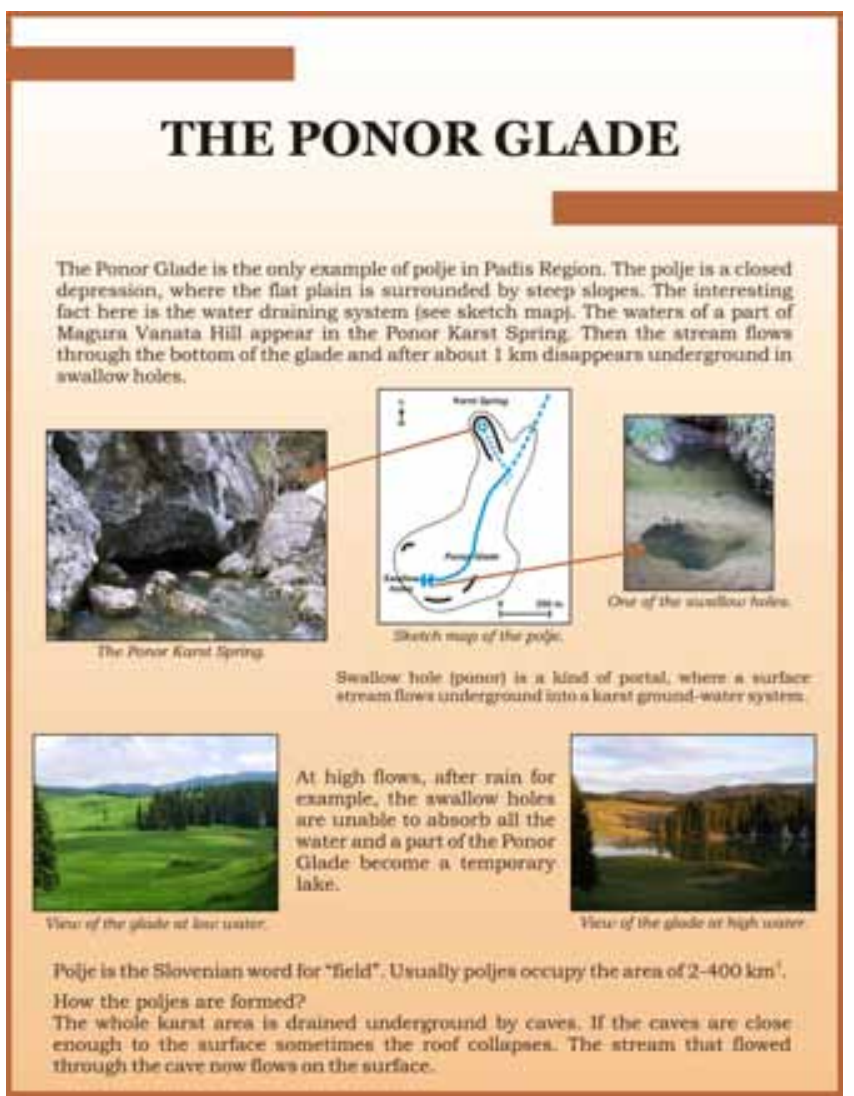

Fig. 16. Proposal of the information panel at the Ponor Glade. Propozycja tablicy informacyjnej przy polanie Ponor.

This paper focuses on the Padis region, one of the most famous and spectacular karst areas in the Carpathians. The visitors can admire there a lot of unique and diverse karst sites, which are characterized by scientific value, convenient location as well as exceptional and scenic form.

On the basis of geotourist assessment result, it was affirmed that six sites are distinguished by high geotourist value and the next six sites - by medium geotourist value. These most

valuable sites, that is: the Focul Viu Ice Cave, the Fortress of Ponor Karst Complex, the Galbena Gorge, the Ponor Glade, the Lumea Pierduta Plateau and the Barsa Karst Depression should be appropriately developed, promoted and used as geotourist sites.

The network of tourist trails, together with easy access by car and accommodation, create a good base for geotourism 
development. What is more, well-organized geotourism, after essential investments, might be a chance for conservation of karst phenomena (reconcile tourist function of this region with necessity of its protection).
In the end, it is also worth noting that not only the Padis plateau, but also the entire Bihor Mountains are characterized by great geotourist potential, thus the creation of geopark in this region should be considered.

\section{Streszczenie \\ Potencjal geoturystyczny krasowego regionu Padis (Góry Apuseni, Rumunia)}

\section{Magdalena Górna}

Region Padis położony jest w północno-zachodniej Rumunii, w północnej części gór Bihor (centralna część gór Apuseni) (Fig. 1). Tradycyjne określenie „,region Padis” dotyczy obszaru leżącego pomiędzy górnymi odcinkami rzek Somesul Cald, Aries oraz Crisul Negru (Móga, 2002). Niniejszy artykuł dotyczy w szczególności potencjału geoturystycznego płaskowyżu Padis (Fig. 2), położonego w centralnej części tego regionu.

Rozpatrywany obszar znajduje się w obrębie jednostki strukturalnej zwanej Północnymi Apuseni (Fig. 1). Jednostkę tą budują proterozoiczne skały metamorficzne oraz paleozoiczne granity, przykryte permo-mezozoiczną pokrywą osadową oraz skałami wulkanicznymi (Burchfiel i in., 1974; Seghedi, 2004). Pokrywa osadowa obejmuje zlepieńce, piaskowce i łupki ( $\mathrm{P}$ i $\left.\mathrm{T}_{1}\right)$, dolomity i wapienie rafowe $\left(\mathrm{T}_{1-2}\right)$, zlepieńce, piaskowce i łupki $\left(\mathrm{J}_{1}\right)$, margle i wapienie $\left(\mathrm{J}_{2,3}\right)$ oraz wapienie, margle i osady turbidytowe $\left(\mathrm{Cr}_{1}\right)$ (Bleahu i in., 1968; Orăşeanu i in., 2007). Obszar Padis budują głównie mezozoiczne skały osadowe, należące do autochtonu Bihor, jednego z trzech głównych elementów tektonicznych Północnych Apuseni. Spośród skał ulegających krasowieniu, w południowej części płaskowyżu dominują wapienie jurajskie, natomiast w części północnej - triasowe wapienie i dolomity (Fig. 3) (Bleahu i in., 1968; Móga, 2002). Występowanie skał węglanowych, jak i takich odpornych na działanie krasu, stworzyło dogodne warunki dla rozwoju urozmaiconej rzeźby. Na stosunkowo niewielkim obszarze zobaczyć można wspaniale wykształcone formy krasu powierzchniowego i podziemnego, jak jaskinie, aweny, ponory, wywierzyska, wąwozy czy leje krasowe. Padis odznacza się ogromnym potencjałem geoturystycznym i nie bez powodu nazywany jest królestwem karpackiego krasu.

W celu wytypowania stanowisk, które powinny być uznane za obiekty geturystyczne, przeprowadzono proces waloryzacji. Podstawą oceny były następujące kryteria: wartość naukowa (unikatowość w stosunku do danego obszaru, stan odsłonięcia i ilustratywność - możliwość obserwacji zjawisk krasowych, ich związek z budową geologiczną), lokalizacja (dostępność - stopień trudności zwiedzania; rozpatrywano jedynie obiekty ogólnodostępne, niewymagające użycia sprzętu speleologicznego) oraz walory dodatkowe obiektów (walory estetyczne, zagospodarowanie, ochrona prawna) (tab. 1). Podczas waloryzacji zastosowano metodę bonitacji punk- towej (Sołowiej, 1992). Należy zaznaczyć, że nie wzięto pod uwagę kryteriów takich jak wielkość stanowiska, czy położenie względem szlaków turystycznych. W przypadku regionu Padis rozpatrywano wyłącznie obiekty wyróżniające się w krajobrazie oraz zlokalizowane bezpośrednio przy szlakach. Wynik waloryzacji przedstawiono w tab. 2.

Poniżej przedstawiono sześć najcenniejszych i najbardziej wartościowych obiektów, które uzyskały wysoką wartość geoturystyczną (wynik powyżej 70\% wartości całkowitej).

Jedną z najsławniejszych jaskiń w obrębie płaskowyżu Padis jest jaskinia lodowa Focul Viu (jaskinia Żywego Ognia). W sali zwanej Big Hall znajduje się lodowa kolumna o wysokości 4-5 m oraz lodowe stalagmity (Fig. 4). Lód pozostaje w jaskini przez cały rok, a jest to spowodowane obecnością otworu w stropie jaskini, przez który zimowe mroźne i cięższe powietrze dostaje się do środka, gdzie zostaje zatrzymane z powodu braku wentylacji (Pop, 1998; Galusek, 2004, Perşoiu i in., 2007).

Twierdza Ponoru jest zdecydowanie najbardziej zadziwiającym i najsławniejszym zespołem obiektów krasowych na terenie Rumunii, jak również w całych Karpatach. Kompleks krasowy tworzą (Fig. 5): dolina z kaskadowym wodospadem zwana Doline 1 (Fig. 6), dwa zapadłe leje krasowe: Doline 2 (Fig. 7) i Doline 3 oraz jaskinia, przez która przepływa podziemny strumień. Jednak zdecydowanie pierwszoplanowym obiektem całego kompleksu jest skalny portal o wysokości 70 m (Fig. 8). Cztery drewniane galerie widokowe umożliwiają podziwianie „,z góry” potęgi i uroku Twierdzy Ponoru (Pop, 1998).

Wąwóz Galbena położony jest poza granicami płaskowyżu Padis. W wywierzysku Galbena (Fig. 9) pojawia się woda z niemal całego opisywanego obszaru (Fig. 2) (Móga, 2002). Pionowe skalne ściany i malownicze wodospady towarzyszą trasie turystycznej wiodącej wzdłuż wąwozu (Fig. 10). Jednak pokonanie szlaku w całości może być trudne, ze względu na niebezpieczne fragmenty oraz zły stan sztucznych udogodnień. Alternatywny szlak prowadzi powyżej wąwozu, a jedną z jego atrakcji jest punkt widokowy (Fig. 11).

Polana Ponor jest jedynym w okolicy przykładem polja (Fig. 12). Interesującym zjawiskiem jest tu powierzchniowopodziemny system wodny. Wody z obszaru grzbietu Magura Vanata pojawiają się w wywierzysku, paradoksalnie nazwanym Ponorem. Następnie strumień płynie przez polanę, aby po około $1 \mathrm{~km}$ zniknąć w kilku ponorach. Podczas wysokiego poziomu wody ponory nie są w stanie w całości jej zaabsorbować i w konsekwencji część polany zamienia się w tymczasowe, malownicze jezioro (Pop, 1998).

Płaskowyż Lumea Pierduta (Zaginiony Świat) przyciąga uwagę ze względu na głębokie aweny. Najgłębszym spośród nich jest Awen Negru (Czarny), który osiąga 108 m głębokości i 50 m średnicy. Mniejszymi formami są Awen Acoperit (Ukryty) oraz najciekawszy, przedzielony kamiennym mo- 
stem Awen Gemanata (Bliźniaczy) (Fig. 13). Aweny Negru i Gemanata połączone są podziemnym systemem korytarzy, których fragment dostępny jest dla speleologów (Pop, 1998; Galusek, 2004).

Podziemia krasowej depresji Barsa kryją wielokilometrowy labirynt korytarzy systemu jaskiniowego Zapodia- Neagre (Fig. 14) (Pop, 1998). Bez specjalistycznego sprzętu eksploracja nie jest jednak możliwa. Dostępny dla wszystkich turystów, przy sprzyjających warunkach, jest natomiast fragment Lodowej Jaskini Barsa.

Płaskowyż Padis znajduje się od 2003 roku w granicach Parku Narodowego Apuseni (www). Ponadto wiele cennych obiektów leżących na tym terenie objętych jest ochroną jako rezerwaty bądź pomniki przyrody (tab. 3). Niestety w terenie brakuje informacji o tym, że cały obszar podlega ochronie prawnej. Jedynie przy trzech obiektach z jedenastu chronionych można znaleźć tablicę informującą o tym fakcie. Warto zauważyć, że negatywny wpływ na przyrodę ma również niekontrolowana turystyka. Rozwój geoturystyki jest szansą na efektywną ochroną obiektów przyrody nieożywionej poprzez uświadamianie zarówno lokalnej społeczności jak turystom unikatowej wartości dziedzictwa geologicznego.
Dostępność komunikacyjna regionu oraz oferta bazy noclegowej poprawiły się w ciągu ostatnich kilku lat. Przez płaskowyż biegnie leśna drogą, łącząca miejscowości Pietrasa $(20 \mathrm{~km})$ oraz Rachitele $(30 \mathrm{~km})$. Bazę noclegową stanowią prywatne pensjonaty, chaty zwane „cabana” oraz „tradycyjne" pola namiotowe (Fig. 2). Jeżeli istniejącą bazę noclegową poszerzyć o punkty informacji turystycznej oraz wesprzeć obiektami agroturystycznymi i dodatkową infrastrukturą na obrzeżach Parku Narodowego Apuseni, płaskowyż Padis mógłby stanowić rdzeń Parku z punktu widzenia zagospodarowania turystycznego (Buza i in., 2001). Do dyspozycji turystów jest ponad $70 \mathrm{~km}$ znakowanych szlaków pieszych (Vagra i in., 2005). Zagospodarowanie turystyczne ma jednak i słabe strony. Są to przede wszystkim: zły stan sztucznych udogodnień na niektórych szlakach (Fig. 15) oraz brak lub zły stan tablic informacyjnych przy atrakcyjnych obiektach (stan na czerwiec 2008).

W celu dostosowania regionu do potrzeb geoturystyki niezbędna jest poprawa stanu technicznego elementów infrastruktury na szlakach, zaprojektowanie tablic informacyjnych (Fig. 16), uruchomienie punktów informacji turystycznej oraz przeprowadzenie akcji promocyjnej.

\section{References (Literatura)}

Bleahu, M., Borcos, M., Saru, H., 1968. Harta Geologica, Brad, 1:200 000. Rep. Soc. Romania. Institulul Geologic, Bucaresti.

Burchfiel, B. C., Bleahu, M., Borcos, M., Patrulius, D., Sandulescu, M., 1974. Geology of Romania. Geology, 2:392-394.

Buza, M., Dimen, L., Pop, G., Turnock, D., 2001. Environmental protection in the Apuseni Mountains: The role of Environmental Non-Governmental Organisations (ENGOs). GeoJournal, 54:631-653.

Galusek, Ł., Jurecki, M., Dumitru, A., 2004. Rumunia. Mozaika w żywych kolorach. Wyd. Bezdroża, Kraków.

Hansen, J., Manoleli, D., Galdean, N., 2002. Biodiversity Assessment Report. Romania 2001. USAID, Romania.

Móga, J., 2002. Morphogenetical karst types of the Transylvanian Mountains (Mt. Apuseni). Acta Carsologica, 31 (3):115-138.

Orăşeanu, I., Parichi, M., Scrădeanu, D., 2007. Intrinsic vulnerability of Cotetul Dobrestilor karst aquifer (Bihor Mountain, Romania). Environ. Geol., 51, 713-718.

Otęska-Budzyn J., 1992. Funkcje obszarów i obiektów chronionych w popularyzacji i dydaktyce nauk o Ziemi. Ochrona Przyrody/ Nature Conservation, $50 \mathrm{cz}$. I, 129-169.
Perşoiu, A., Feier, I., Citterio, M., Turri, S., Maggi, V., 2007. Preliminary data on air temperature in Focul Viu Ice Cave (Bihor Mts., Romania). In: Zelinka, J. (eds.) Proceedings of the 2nd International Workshop on Ice Caves, Demanovská Dolina, Slovak Republic, 8-12 May 2006, 62-64. Pop, C., 1998. Padis, monograph. Clubul Ecologic Transilvania, Cluj-Napoca. Pralong, J. P., 2005. A method for assessing tourist potential and use of geomorphological sites. Géomorphologie: relief, processus, environnement, 3:189-196.

Seghedi, I., 2004. Geological evolution of the Apuseni Mountains with emphasis on the Neogene magmatism- a review. In: Cook, N. J. \& Ciobanu, C. L. (eds.) Au-Ag-telluride Deposits of the Golden Quadrilateral, Apuseni Mts., Romania, Guidebook of the International Field Workshop of IGCP project 486:5-23.

Sołowiej, D., 1992. Podstawy metodyki oceny środowiska przyrodniczego człowieka. Wyd. Nauk. UAM, Poznań.

Vagra, A. (ed.) 2005. A bihari Padis karsztvideke, 1:30 000. Dimap, Budapest.

www.parcapuseni.ro 